Neurol Clin. 2007 August ; 25(3): 741-vii. doi:10.1016/j.ncl.2007.03.001.

\title{
Dementia with Lewy bodies
}

\author{
Tanis J. Ferman, $\mathrm{PhD}^{1}$ and Bradley F. Boeve, $\mathbf{M D}^{2}$ \\ ${ }^{1}$ Mayo Clinic College of Medicine, Jacksonville FL \\ ${ }^{2}$ Mayo Clinic College of Medicine, Rochester MN
}

\section{Synopsis}

The advent of new immunostains have improved our ability to detect limbic and cortical Lewy bodies, and it is now evident that Dementa with Lewy bodies (DLB) is the second most common neurodegenerative dementia, after Alzheimer's disease (AD). Distinguishing DLB from AD has important implications for treatment, in terms of substances that may worsen symptoms (i.e., anticholinergic and certain neuroleptic medications) and those that may improve them (i.e., cholinesterase inhibitors, carbidopa-levodopa). Neurocognitive patterns, psychiatric features, extrapyramidal signs and sleep disturbance are helpful in differentiating DLB from AD early in the disease course. Differences in the severity of cholinergic depletion as well as type and distribution of neuropathology contribute to these clinical differences, though DLB patients with a high density of co-occuring $\mathrm{AD}$ pathology are less clinical distinguishable from $\mathrm{AD}$.

\section{Keywords}

Lewy bodies; dementia; parkinsonism; hallucinations; fluctuations

\section{Introduction}

Neocortical Lewy bodies are found in about $20-35 \%$ of elderly persons with dementia (1-4) and do not commonly occur in normal brains (5). Based on sensitive immunostaining techniques, dementia with Lewy bodies (DLB) is now considered the second most common cause of neurodegenerative dementia following Alzheimer's disease (AD)(5,6). In 1996, consensus criteria for the clinical diagnosis of DLB were put forth that require dementia plus one or two of the following core features (2 for probable DLB, 1 for possible DLB):

Recurrent fully formed visual hallucinations ( $\mathrm{VH})$, parkinsonism and fluctuating cognition. (7) Using these criteria, diagnostic accuracy varies from poor to excellent(8-11). Problems with reliable assessment of fluctuations, a lack of empiric data regarding when core features should occur relative to dementia onset, and limitations to study design (e.g., circularity, absence of standardized assessment, inclusion of cases with advanced dementia) contribute to this discrepancy(12-16). The $3^{\text {rd }}$ international workshop on DLB and Parkinson's disease dementia (PDD) convened in 2003 and revised consensus diagnostic criteria have been recently published (17). These criteria are presented in Table 1.

Address correspondence to: Tanis J. Ferman, PhD, Dept of Psychiatry \& Psychology, Mayo Clinic, 4500 San Pablo Rd, Jacksonville, FL 32224, Tel: (904) 953-8007, Fax: (904) 953-0461, ferman.tanis@ mayo.edu.

Publisher's Disclaimer: This is a PDF file of an unedited manuscript that has been accepted for publication. As a service to our customers we are providing this early version of the manuscript. The manuscript will undergo copyediting, typesetting, and review of the resulting proof before it is published in its final citable form. Please note that during the production process errors may be discovered which could affect the content, and all legal disclaimers that apply to the journal pertain. 


\section{Neuropsychological Function}

The dementias of DLB and AD are similar in insidious onset and progressive course, and prior to autopsy, many patients with Lewy body disease are given the antemortem diagnosis of $\operatorname{AD}(3,13)$. Despite some similarities, several studies show greater deficits in attention and visual-perception in DLB, while AD is associated with worse memory and naming $(3,18$ 20). Logistic regression modeling was done to determine the diagnostic utility of cognitive assessment in the differentiation of a prospective sample of persons with DLB $(n=87)$ from those with $\mathrm{AD}(\mathrm{n}=138)$ and normal aging $(\mathrm{n}=103)(21)$. Patient groups did not differ in age, education or dementia severity. The logistic models reveal that impairment in basic attention, visual perception, visual construction and memory distinguished DLB from normal aging (sensitivity of $88.6 \%$, specificity of $96.1 \%$ ). In contrast, impaired visual construction and attention plus preserved memory and naming skills distinguished DLB from AD (sensitivity of $83.3 \%$ and a specificity of $91.4 \%$ ). These results confirm our prior findings of a double dissociation in neurocognitive function between early DLB and $\mathrm{AD}(21)$.

The higher order visual processing deficits in DLB is a finding that is not attributable to motor slowness associated with parkinsonism(3,20,22-26). The perceptual deficits evident in DLB may be responsible for some misperceptions (i.e., illusions) and delusional misidentification (i.e., not recognizing family, reduplicative paramnesia). Interestingly, DLB patients with visual hallucinations tend to do more poorly on visual tasks(19-25,27). Nonetheless, some studies have not found differences between AD and DLB on visual tasks $(28,29)$, though this may be due to methodologic issues, such as the inclusion of patients in the advanced stages of dementia which can obfuscate group differences due to generalized impairment. Alternately, differential impairment of other task demands may be a factor. For example, visual problem solving may be negatively affected by executive difficulties in AD, and by perceptual difficulties in DLB. Mori and colleagues examined this issue and revealed deficits in DLB but not AD on basic visual tasks that do not require executive function(30). Also, a distinction between spatial and perceptual processing seems to be a distinguishing factor as well, with DLB patients showing greater deficits in the latter(31). There may be group differences in how the information is initially encoded. Reflexive saccadic eye movements responsible for repositioning the fovea show greater impairment for DLB compared to $\mathrm{AD}(32)$, and regional blood flow has been shown to be lower in occipital regions in DLB despite the relative absence of Lewy pathology there (3336). Overall, visual processing deficits in DLB may be due to disruption of the cortical extra-striate association areas (especially the ventral visual pathway), but there may also be disruption to the afferent system (perhaps via mechanisms subserving saccadic foveation) before reaching the primary visual cortex.

Memory difficulties, when present in early DLB, appear to be fairly mild and stand in direct contrast to the pronounced amnestic disturbance of $\mathrm{AD}(18-20)$. Neuropathologic and imaging studies also show significant atrophy in the hippocampus in $\mathrm{AD}$, while patients with DLB show little difference from normal controls(37-39). Salmon and colleagues(18) demonstrated a pattern of poor initial learning and retrieval in 4 of 5 patients with DLB without the rapid forgetting that is typically observed in AD. In a sample of 9 pure DLB, 57 mixed $\mathrm{DLB} / \mathrm{AD}$ and 66 pure $\mathrm{AD}$, patients with $\mathrm{AD}$ pathology performed worse on tasks of verbal memory while patients with LB pathology performed worse on tasks of visual spatial skills, and combined pathology affected visual spatial performance but not verbal memory(40). 


\section{Spontaneous Motor Features of Parkinsonism}

For diagnostic clarity, parkinsonian signs must be spontaneous and not attributable to neuroleptics(7). Cognitive impairment in PD and DLB is more often associated with rigidity and bradykinesia than tremor(41-50). Postural instability/gait difficulty is over-represented in DLB and PDD compared to PD(51), and this has led some to speculate extrapyramidal signs associated with dementia may have a dopaminergic and non-dopaminergic basis. In general, the parkinsonism associated with DLB tends to be less severe than that observed in PD or PDD, at least initially. Tremor, bradykinesia and rigidity tend to be more symmetric than asymmetric, and tremor tends to be maximal with posture/action rather than at rest. One study of 14 DLB, 28 PD and 30 PDD patients showed improvement in Unified Parkinson's Disease Rating Scale (UPDRS) score for all 3 groups in response to 1-dopa, but less so for the DLB patients(52). The possibility that this effect may be mediated by greater initial motor deficits in the PDD and PD groups should be considered.

\section{Visual Hallucinations}

Visual hallucinations (VH) in DLB consist of fully formed, detailed, three-dimensional objects, people or animals that are not attributable to perceptual distortion or illusion $(3,47,53)$. DLB patients with auditory hallucinations (AH) typically experience $\mathrm{VH}$, but $\mathrm{AH}$ rarely occur in patients without $\mathrm{VH}(54,55)$. Hallucinations in DLB do not occur as a function of $\mathrm{AD}$ pathology(56) and are not associated with levodopa dose or the presence of "on" (able to move) and "off" (unable to move) states(57). VH have been documented to occur in 59-85\% of autopsy confirmed DLB samples, and in 11-28\% of autopsy confirmed AD samples $(5,15,58,59)$. Autopsy studies reveal that $\mathrm{VH}$ are most likely to occur early in DLB disease course while they tend to occur in the advanced stages of AD $(5,60-62)$. In an autopsy study of $41 \mathrm{DLB}$ and $70 \mathrm{AD}$, a cut-off of 4 years for the onset of hallucinations relative to dementia onset improved the positive and negative predictive values of DLB to $81 \%$ and $79 \%$, respectively(63). Patients with VH typically have greater cognitive and functional impairment(64-68), but whether the presence of VH in DLB is associated with faster rate of disease progression has yet to be determined. The underlying cause of hallucinations is most likely associated with the severe depletion of acetylcholine in DLB, but other neurotransmitter systems may have a contributory role, including dopamine and serotonin. Involvement of the basal forebrain and the ventral temporal lobe have been implicated in the causation of visual hallucinations given their respective cholinergic and visual perceptual roles $(5,58)$. Also, the dysregulation of rapid eye movement (REM) sleep in many patients with DLB, raises the possibility that the intrusion of dream imagery into wakefulness as a potential mechanism $(69,70)$. These etiologies are not necessarily mutually exclusive.

\section{Fluctuations}

The fluctuations of DLB resemble signs of delirium without identifiable precipitants of such mental status changes. This phenomenon involves a waxing and waning of cognition, abilities and arousal. It has been described as variable attention, incoherent speech, hypersomnolence, impaired awareness of surroundings, staring into space, or appearing "glazed" or "switched off". The prevalence of fluctuations in DLB samples is widely discrepant and ranges from 10 to $80 \%$ with poor inter-rater reliability $(8,10,12,71,72)$. Studies typically do not specify how the presence of fluctuations was determined and the usefulness of this core clinical feature has been highly criticized. Available techniques to assess fluctuations include a brief interview rating scale relying on clinical expertise, a semistructured interview that inquires about the day before the assessment(16,73-76), and a set of 4 questions derived from a lengthier questionnaire (77). The latter questionnaire was 
designed to determine whether there are salient features of fluctuations that reliably differentiate DLB $(n=70)$ from AD $(n=70)$ and normal elderly $(n=200)$. Results show that four items significantly differentiated DLB from AD and include: 1 . daytime drowsiness and lethargy, 2. daytime sleep of 2 or more hours, 3 . staring into space for long periods and 4. times when the patient's flow of ideas seem disorganized, unclear or not logical. The presence of 3 or 4 features of this composite occurred in $63 \%$ of DLB compared to $12 \%$ of $\mathrm{AD}$ and $0.5 \%$ normal elderly $(\mathrm{p}<0.01)$. A score of 3 or 4 yields a positive predictive value of $83 \%$ for the clinical diagnosis of DLB against an alternate diagnosis of AD, and a score of less than 3 yields a negative predictive value of $70 \%$ for the absence of DLB in favor of AD. Since not all patients with DLB have fluctuations, these values suggest reasonable diagnostic utility. No particular combination of visual hallucinations, parkinsonism (presence or severity) or RBD was associated with a fluctuations composite score of 3 or 4 . (77) These data indicate that an informant-based questionnaire is sensitive to fluctuations in alertness and speech, but fails to differentiate fluctuations in ability or cognition between DLB and AD. It may be worthwhile to distinguish between fluctuations in arousal and cognition, whereby the latter may be best evaluated with neuropsychometric tests. This is supported by findings that attention, vigilance and reaction time show greater impairment and variability in DLB than in AD $(20,73,75)$.

\section{Excessive daytime drowsiness}

Patients with DLB often have daytime drowsiness or somnolence. As such, ruling out known causes of daytime sleepiness, including medications and primary sleep disorders (i.e., sleep apnea) is critical. In a clinical referral sample of 78 patients with early DLB who underwent overnight polysomnography, about $3 / 4$ of the sample had a significant number of arousals not accounted for by medication, periodic limb movements of sleep or sleep apnea $(78,79)$. In half of the DLB sample, sleep efficiency fell well below the expected $80 \%$ for this age group (80-82). This raises the possibility that dysfunction of brainstem and/or hypothalamic neuronal networks subserving sleep/wakefulness may be producing daytime drowsiness. Further studies are needed that represent a random selection of DLB patients and an $\mathrm{AD}$ group matched for age, gender and dementia severity.

\section{REM Sleep Behavior Disorder (RBD)}

The loss of normal muscle atonia during rapid eye movement (REM) sleep refers to the parasomnia of REM Sleep Behavior Disorder (RBD). In RBD, augmented muscle activity during REM sleep occurs along with altered dream content, and can range from elevated muscle tone to complex behavioral sequences such as pantomiming various activities that may be subdued or quite vigorous $(22,83)$. The presumed pathophysiologic mechanism of $\mathrm{RBD}$, involves damage to the descending pontine-medullary reticular formation (including the magnocellular reticular formation) and/or sublaterodorsal nucleus that leads to a loss of the normal REM sleep inhibition of the spinal alpha-motoneurons (84-87). In humans, polysomnographic evidence of REM sleep without atonia is considered the electrophysiologic substrate of RBD and has been found in patients with and without florid RBD $(88,89)$. RBD can precede the onset of neurodegenerative diseases with alphasynuclein inclusions (i.e., DLB, Parkinson's disease, Multiple System Atrophy) by years and even decades $(22,89-94)$. It rarely occurs in tau-predominant neurodegenerative conditions, such as Alzheimer's disease (92). Neuropathologic confirmation of Lewy body disease has been demonstrated in a patient with a 20-year history of idiopathic RBD (93), and in a patient with a 15 -year history of idiopathic $\operatorname{RBD}(94)$, neither of whom had any other neurologic signs or symptoms or evidence of psychosis. Out of 36 patients with clear clinical histories of RBD, 31 had Lewy body disease, 4 had Multiple System Atrophy and 1 
has progressive supranuclear palsy, providing further evidence that RBD usually reflects an underlying synucleinopathy (95).

The estimated onset of RBD typically precedes the onset of dementia, visual hallucinations and parkinsonism by many years and often decades (range $=6$ months to 55 years) $(19,20,22)$. Despite this relationship, patients who initially present with dementia and RBD will not meet formal DLB criteria until parkinsonism or hallucinations become apparent. We examined the neurocognitive performance of 25 patients with RBD and dementia (without parkinsonism or hallucinations) and compared them to 37 patients with clinically probable DLB and 30 autopsy-confirmed AD of matched dementia severity (19). Results indicate that the DLB and RBD plus dementia groups were cognitively indistinguishable, but both groups significantly differed from autopsy-confirmed AD patients of matched dementia severity. Follow-up data from a subset of patients with RBD plus dementia revealed the subsequent development of parkinsonism and/or VH one to six years later. Thus, a clinical history of RBD in the context of dementia with disproportionate visual deficits and relatively preserved memory and naming is likely to represent the earliest stages of DLB.

\section{Dysautonomia}

Autonomic abnormalities, in particular orthostatic hypotension and carotid sinus sensitivity are more common in DLB than AD or elderly controls (17). A comparison of dysautonomia in DLB, PD and MSA shows that orthostatic hypotension is quite common in all 3 groups but MSA is the most severely affected, PD is least severely affected, and DLB has intermediate severity (96). The DLB group tended to respond better to medications than those with MSA. The frequency of urinary symptoms and pattern of sweat loss in DLB was comparable to that of PD but much less than MSA.

\section{Rate of decline in DLB}

Several studies of DLB indicate a more rapid progression than that of pure AD, and earlier studies of AD suggested extrapyramidal features and psychosis are predictors of decline $(13,48,97-100)$. Some recent data, however, shows no difference in rate of cognitive decline between DLB and AD $(101,102)$. In an autopsy study with patients who were part of the Florida Alzheimer's Disease Initiative Brain Bank, there was a shorter duration of illness for DLB compared to AD (63). In a longitudinal study of 63 DLB and 252 AD patients, psychometric performance and clinical staging methods did not distinguish groups in terms of rate of cognitive decline, but DLB is associated with increased risk of mortality. Extrapyramidal signs were strong predictors of mortality (103).

\section{Description and distribution of pathology in DLB}

Lewy bodies are concentric, intra-cytoplasmic neuronal inclusions that have long been a recognized pathology of brainstem monoaminergic and cholinergic nuclei in idiopathic Parkinson's disease (PD) $(104,105)$. Subcortical Lewy bodies are distributed in the dorsal motor nucleus of the vagus, medullary magnocellular reticular nuclei, locus coeruleus, raphe nucleus, midbrain tegmentum, hypothalamus and basal forebrain (106-109). Neocortical Lewy bodies are less eosinophilic, less circumscribed, and are better detected by ubiquitin, but particularly by $\alpha$-synuclein immunohistochemistry, which is now considered the gold standard (106). The limbic and temporal regions are particularly vulnerable to "cortical" Lewy bodies, with lesser involvement of frontal and posterior cortical regions (108-111). Spongiosis is also observed in the amygdala and basal forebrain (106). Similarly, using magnetic resonance imaging (MRI), the rates of whole brain atrophy and ventricular expansion over a 1 to 2 year interval do not differ between a sample of DLB later confirmed by autopsy and normal controls (112). When compared to AD, MRI voxel based 
morphometry reveals that DLB has very little cortical involvement but does show a discrete cluster of grey matter loss in the cholinergic-rich regions of the nucleus basalis of Meynert in the basal forebrain and dorsal midbrain (113).

Lewy neurites (LN) are widespread alpha-synuclein positive inclusions that are located in neural processes, and preferentially affect limbic and temporal lobe structures $(37,38,107)$.

A proportion of DLB cases have AD-type pathology that include neurofibrillary tangles (NFTs) and neuritic plaques $(3,4,13)$. Plaques are composed of extracellular beta-amyloid (Ab) protein deposits comprised of 40 and 42 amino acid peptides. The neuritic plaques that accompany $\mathrm{AD}$ include a dense core of Ab40 with neuritic processes composed of the protein tau (114). In contrast, plaques in Lewy body disease are typically diffuse (though some may contain a core), and are primarily composed of $\mathrm{Ab} 42$ with a paucity or absence of tau-positive neuritis (115-119). Diffuse plaques are also numerous in brains of cognitively normal elderly $(37,120,121)$. Most clinico-pathologic studies of DLB and AD do not take this distinction into account, and as such, it is not known whether differences in plaque-type influence clinical presentation. When NFTs are present in Lewy body disease, they are far less frequent than in $\mathrm{AD}$, and regional distribution using Braak staging is often at Braak IV or less indicating confinement to limbic regions $(3,47,122-125)$. Clinical diagnostic accuracy of DLB is significantly better in those with low Braak stages and lower tangle density $(126,127)$.

\section{Clinico-pathologic correlates in DLB and AD}

Dementia severity is not associated with neocortical plaque density but is related to NFT burden in AD $(123,128,129)$. In DLB, LB density but not plaque or NFT density is correlated with dementia severity $(123,130,131)$. LN density has also been associated with the degree of cognitive impairment in DLB (132), suggesting that these inclusions may interfere with neuronal function, but further investigation is needed.

In $\mathrm{AD}$, the $\mathrm{CA} 1$ region and subiculum of the hippocampus are severely affected while the CA2/3 region is considered the "resistant zone" and is typically spared (133-135). In DLB it is the $\mathrm{CA} 2 / 3$ region that is affected while the CA1 and subiculum regions are typically spared $(37,136)$. Similarly, AD is associated with a near total loss of perforant pathway neurons while in DLB, the perforant pathway is more comparable to that of normal controls (137). Although damage to the CA1 region has been associated with memory impairment, is not known whether CA2/3 pathology affects memory function.

The ventral temporal lobe is heavily burdened by prominent Lewy body pathology and spongiosis $(48,106)$. This neuroanatomic pattern appears to occur well before the onset of Lewy body pathology in other cortical regions, including the parietal lobe (110). Thus, early specific visual perceptual deficits may be associated with disruption of the pattern/object recognition pathway. Patients with VH have higher LB densities in amygdala, parahippocampus and inferior temporal cortex (136), suggesting the involvement of these regions in the development of $\mathrm{VH}$. Nonetheless, $\mathrm{VH}$ can and do occur in patients with limbic only pathology (63).

\section{The cholinergic hypothesis fits DLB better than AD}

The use of new cholinergic toxins to selectively target the nucleus basalis of Meynert (which is $90 \%$ cholinergic and widely projects to the cortex) (138) reveals no impairment of memory, but does reveal deficits in sustained and divided attention (139-143). In addition, profound cholinergic neuronal loss and severely depleted choline acetyltransferase levels occur early in DLB disease course, while AD and normal controls show little difference 
until the advanced stage of dementia (144-147). In addition, anticholinergic agents can elicit hallucinations and disturbed consciousness that vary as a function of cholinergic deficiency (148-153). Not surprisingly, one hypothesized mechanism for fluctuations and visual hallucinations in DLB includes cholinergic depletion of the basal forebrain alone $(5,145,149,154)$. Increasing acetylcholine availability with cholinesterase inhibitors improves attention, hallucinations and alertness in early DLB (154-159). Thus, cholinergic depletion is a critical factor in the symptom manifestation of early DLB but may be less so in early AD. This highlights the importance of differentiating between early versus late stages of different dementias, since patients with advanced AD may have similar clinical features as those with early DLB.

\section{Pharmacologic treatment of DLB}

When faced with a challenging behavior, it is critical to first evaluate for potential medical contributors (e.g., pain, medication side effects, injury, underlying sleep disorder, depression, dehydration, metabolic disturbance), and treat accordingly.

Neuroleptic medication is frequently administered to dementia patients for episodic confusion, hallucinations, delusions and agitation $(160,161)$. These clinical features are commonly observed in DLB, but there is convincing evidence that patients with DLB can harbor neuroleptic sensitivity to traditional and to some atypical neuroleptics $(59,162-166)$. Specifically, antipsychotic agents with D2 antagonism and anticholinergic properties precipitate and/or exacerbate extrapyramidal signs and cognitive impairment, respectively $(167,168)$. Unfortunately, discontinuation of the neuroleptic does not necessarily lead to a reversal of the adverse reaction (59). There is a mixed literature on the relationship between atypical antipsychotics and cognition, though the effects of quetiapine appear to be better in DLB than in AD (169-174). Olanzepine does not seem to worsen parkinsonism (169), though its anticholinergic properties may exacerbate cognitive impairment (172).

Levodopa-carbidopa is generally well tolerated in DLB, but response may not be at the magnitude in some patients as seen in patients with PD (51). There are reports of levodopacarbidopa having a positive impact on cognition $(175,176)$.

Brain acetylcholine is profoundly depleted in the early stages of DLB compared to AD $(5,145-147)$. This is concerning because drugs with anticholinergic properties are often prescribed to the elderly to treat mood, psychosis, movement disorders, incontinence and pulmonary disease (150). Several studies have clearly demonstrated adverse reactions to anticholinergic agents that mimic delirium (151-153,177). Alternately, improvement (sometimes dramatic) in delirium-like or fluctuating symptoms (including $\mathrm{VH}$ ) can occur with the use of cholinesterase inhibitors $(146,178-181)$. Studies of cholinesterase inhibitors (182-184) reveal improved cognition in DLB and AD, and detrimental effects when suddenly withdrawn (185). A comparison of 30 DLB and 40 PDD with donepezil revealed improved MMSE scores by a mean of 3.9 points in the DLB group and by 3.2 points in PDD by 20 weeks.(186) Extrapyramidal side effects of cholinesterase inhibitors are actually quite low, and it is recommended as a first-line treatment for DLB (187).

The goals of therapy for RBD are to minimize the injuries to patients and their bedpartners and to reduce the likelihood of disrupted nighttime sleep. Clonazepam at a very low dose ( 0.25 to $0.5 \mathrm{mg}$ at night) is usually effective (188). Melatonin may also be effective at 3 to $12 \mathrm{mg}$ per night, either as monotherapy or in conjunction with clonazepam (189).

Excessive daytime sleepiness is challenging and the first approach is to try to identify whether the cause may be a medication side effect, mood or a primary sleep disorder. Although psychostimulants would be expected to exacerbate hallucinations and delusions in 
DLB, experience has shown that daytime somnolence in some patients can be managed with agents such as modafinil and methylphenidate (190).

\section{Non-pharmacologic treatment}

Behaviors should be recognized as a form of communication and not as random, unpredictable or meaningless events. It may be helpful to determine which situations the behavior tends to occur (who is present, when does it happen, what makes it better or worse, what maintains it), and to focus on the emotion that accompanies the behavior. For example, aggressive behavior often represents frustration, fear, pain, a reaction to feelings of not being taken seriously or even mirroring of caregiver's behavior (i.e., impatience, agitation). Addressing these feelings may help to alleviate the patient's agitation.

In terms of non-medical interventions, managing challenging behaviors should be shifted from trying to change the patient to modifying other factors that may be causing or exacerbating the problem (191). Put differently, the patient cannot change, and therefore, it is up to those around him to change. This includes modifying the environment (e.g, reducing clutter, modifying illumination, reducing distracting noise), how we respond to behavior (e.g., validating the patient's concerns, apologizing, reassuring the patient, avoid correcting or quizzing the patient, model calm, avoid trying to "reality orient"), examining task demands (e.g., providing structure and routine, providing repetitive tasks, providing exercise, breaking down tasks into more manageable parts, focus on successes and not failures, refrain from giving tasks that are too hard).

Before treating hallucinations or delusions (false beliefs), it must be determined whether these symptoms are actually harmful or distressing to the patient. Educating the family member about ways to cope with these behaviors include encouraging them to validate the patient's feelings and devising strategies that 'go along' with the behavior (e.g., checking the house for intruders, appearing to call somebody to see what time is check-out time), that provide reassurance, and that does not involve arguing or trying to reason with the patient.

Providing information for the caregiver is an important part of helping to manage challenging behaviors. Psychoeducation intervention groups for caregivers have been associated with significant improvements in agitation and anxiety for dementia patients (192). Utilizing available support services, including adult day programs and companion services have also been shown to reduce caregiver related stress and reported feelings of overload, strain, depression and anger (193).

\section{Conclusions}

Clinical features that may be helpful in distinguishing early DLB from AD include neurocognitive presentation, visual hallucinations, extrapyramidal signs, fluctuations, neuroleptic sensitivity, REM sleep behavior disorder and dysautonomia. Early and accurate detection of DLB has implications for symptom management and for providing education and support to DLB patients and their caregivers.

\section{Acknowledgments}

Supported by NIH grants R01-AG15866, P50-AG16574, P50-NS40256 


\section{References}

1. Galasko D, Hansen LA, Katzman R, Wiederholt W, Masliah E, Terry R, Hill LR, Lessin P, Thal LJ. Clinical-neuropathological correlations in Alzheimer's disease and related dementias. Arch Neurol. 1994; 51:888-95. [PubMed: 8080388]

2. Joachim CL, Morris JH, Selkoe DJ. Clinically diagnosed Alzheimer's disease: autopsy results in 150 cases. Ann Neurol. 1988; 24:50-6. [PubMed: 3415200]

3. Hansen L, Salmon D, Galasko D, Masliah E, Katzman R, DeTeresa R, Thal L, Pay MM, Hofstetter R, Klauber M, et al. The Lewy body variant of Alzheimer's disease: a clinical and pathologic entity. Neurology. 1990; 40:1-8. [PubMed: 2153271]

4. Hulette C, Mirra S, Wilkinson W, Heyman A, Fillenbaum G, Clark C. The Consortium to Establish a Registry for Alzheimer's Disease (CERAD). Part IX. A prospective cliniconeuropathologic study of Parkinson's features in Alzheimer's disease. Neurology. 1995; 45:1991-5. [PubMed: 7501147]

5. Perry EK, Marshall E, Perry RH, Irving D, Smith CJ, Blessed G, Fairbairn AF. Cholinergic and dopaminergic activities in senile dementia of Lewy body type. Alzheimer Dis Assoc Disord. 1990; 4:87-95. [PubMed: 2357341]

6. Lennox G, Lowe J, Landon M, Byrne EJ, Mayer RJ, Godwin-Austen RB. Diffuse Lewy body disease: correlative neuropathology using anti-ubiquitin immunocytochemistry. J Neurol Neurosurg Psychiatry. 1989; 52:1236-47. [PubMed: 2556498]

7. McKeith IG, Galasko D, Kosaka K, Perry EK, Dickson DW, Hansen LA, Salmon DP, Lowe J, Mirra SS, Byrne EJ, Lennox G, Quinn NP, Edwardson JA, Ince PG, Bergeron C, Burns A, Miller BL, Lovestone S, Collerton D, Jansen EN, Ballard C, de Vos RA, Wilcock GK, Jellinger KA, Perry RH. Consensus guidelines for the clinical and pathologic diagnosis of dementia with Lewy bodies (DLB): report of the consortium on DLB international workshop. Neurology. 1996; 47:1113-24. [PubMed: 8909416]

8. McKeith IG, Ballard CG, Perry RH, Ince PG, O’Brien JT, Neill D, Lowery K, Jaros E, Barber R, Thompson P, Swann A, Fairbairn AF, Perry EK. Prospective validation of consensus criteria for the diagnosis of dementia with Lewy bodies. Neurology. 2000; 54:1050-8. [PubMed: 10720273]

9. Lopez OL, Becker JT, Kaufer DI, Hamilton RL, Sweet RA, Klunk W, DeKosky ST. Research evaluation and prospective diagnosis of dementia with Lewy bodies. Arch Neurol. 2002; 59:43-6. [PubMed: 11790229]

10. Verghese J, Crystal HA, Dickson DW, Lipton RB. Validity of clinical criteria for the diagnosis of dementia with Lewy bodies. Neurology. 1999; 53:1974-82. [PubMed: 10599768]

11. Litvan I, MacIntyre A, Goetz CG, Wenning GK, Jellinger K, Verny M, Bartko JJ, Jankovic J, McKee A, Brandel JP, Chaudhuri KR, Lai EC, D'Olhaberriague L, Pearce RK, Agid Y. Accuracy of the clinical diagnoses of Lewy body disease, Parkinson disease, and dementia with Lewy bodies: a clinicopathologic study. Arch Neurol. 1998; 55:969-78. [PubMed: 9678315]

12. Mega MS, Masterman DL, Benson DF, Vinters HV, Tomiyasu U, Craig AH, Foti DJ, Kaufer D, Scharre DW, Fairbanks L, Cummings JL. Dementia with Lewy bodies: reliability and validity of clinical and pathologic criteria. Neurology. 1996; 47:1403-9. [PubMed: 8960718]

13. Lippa CF, Smith TW, Swearer JM. Alzheimer's disease and Lewy body disease: a comparative clinicopathological study. Ann Neurol. 1994; 35:81-8. [PubMed: 8285597]

14. Kuzuhara S, Yoshimura M. Clinical and neuropathological aspects of diffuse Lewy body disease in the elderly. Adv Neurol. 1993; 60:464-9. [PubMed: 8420171]

15. Klatka LA, Louis ED, Schiffer RB. Psychiatric features in diffuse Lewy body disease: a clinicopathologic study using Alzheimer's disease and Parkinson's disease comparison groups. Neurology. 1996; 47:1148-52. [PubMed: 8909420]

16. Walker MP, Ayre GA, Cummings JL, Wesnes K, McKeith IG, O'Brien JT, Ballard CG. The Clinician Assessment of Fluctuation and the One Day Fluctuation Assessment Scale. Two methods to assess fluctuating confusion in dementia. Br J Psychiatry. 2000; 177:252-6. [PubMed: 11040887]

17. McKeith IG, Dickson DW, Lowe J, Emre M, O’Brien JT, Feldman H, Cummings J, Duda JE, Lippa C, Perry EK, Aarsland D, Arai H, Ballard CG, Boeve B, Burn DJ, Costa D, Del Ser T, Dubois B, Galasko D, Gauthier S, Goetz CG, Gomez-Tortosa E, Halliday G, Hansen LA, Hardy J, 
Iwatsubo T, Kalaria RN, Kaufer D, Kenny RA, Korczyn A, Kosaka K, Lee VM-Y, Lees A, Litvan I, Londos E, Lopez OL, Minoshima S, Mizuno Y, Molina JA, Mukaetova-Ladinska EB, Pasquier F, Perry RH, Schulz JB, Trojanowski JQ, Yamada M. for the consortium on DLB. Diagnosis and management of dementia with Lewy bodies: Third report of the DLB consortium. Neurology. 2005; 65:1863-1872. [PubMed: 16237129]

18. Salmon DP, Galasko D, Hansen LA, Masliah E, Butters N, Thal LJ, Katzman R. Neuropsychological deficits associated with diffuse Lewy body disease. Brain Cogn. 1996; 31:148-65. [PubMed: 8811990]

19. Ferman TJ, Boeve BF, Smith GE, Silber MH, Lucas JA, Graff-Radford NR, Dickson DW, Parisi JE, Petersen RC, Ivnik RJ. Dementia with Lewy bodies may present as dementia and REM sleep behavior disorder without parkinsonism or hallucinations. J Int Neuropsychol Soc. 2002; 8:90714. [PubMed: 12405541]

20. Ferman TJ, Boeve BF, Smith GE, Silber MH, Kokmen E, Petersen RC, Ivnik RJ. REM sleep behavior disorder and dementia: cognitive differences when compared with AD. Neurology. 1999; 52:951-7. [PubMed: 10102411]

21. Ferman TJ, Smith GE, Boeve BF, Graff-Radford N, Lucas JA, Knopman D, Petersen R, Barnes S, Ivnik RJ. Neuropsychological differentiation of dementia with Lewy bodies from normal aging and Alzheimer's disease. Clin Neuropsychol. 2006; 20:623-636. [PubMed: 16980250]

22. Boeve BF, Silber MH, Ferman TJ, Kokmen E, Smith GE, Ivnik RJ, Parisi JE, Olson EJ, Petersen RC. REM sleep behavior disorder and degenerative dementia: an association likely reflecting Lewy body disease. Neurology. 1998; 51:363-70. [PubMed: 9710004]

23. Calderon J, Perry RJ, Erzinclioglu SW, Berrios GE, Dening TR, Hodges JR. Perception, attention, and working memory are disproportionately impaired in dementia with Lewy bodies compared with Alzheimer's disease. J Neurol Neurosurg Psychiatry. 2001; 70:157-64. [PubMed: 11160462]

24. Ballard C, Holmes C, McKeith I, Neill D, O’Brien J, Cairns N, Lantos P, Perry E, Ince P, Perry R. Psychiatric morbidity in dementia with Lewy bodies: a prospective clinical and neuropathological comparative study with Alzheimer's disease. Am J Psychiatry. 1999; 156:1039-45. [PubMed: 10401449]

25. Shimomura T, Mori E, Yamashita H, Imamura T, Hirono N, Hashimoto M, Tanimukai S, Kazui H, Hanihara T. Cognitive loss in dementia with Lewy bodies and Alzheimer disease. Arch Neurol. 1998; 55:1547-52. [PubMed: 9865799]

26. Connor DJ, Salmon DP, Sandy TJ, Galasko D, Hansen LA, Thal LJ. Cognitive profiles of autopsyconfirmed Lewy body variant vs pure Alzheimer disease. Arch Neurol. 1998; 55:994-1000. [PubMed: 9678318]

27. Simard M, van Reekum R, Myran D. Visuospatial impairment in dementia with Lewy bodies and Alzheimer's disease: a process analysis approach. Int J Geriatr Psychiatry. 2003; 18:387-91. [PubMed: 12766913]

28. Forstl H, Burns A, Luthert P, Cairns N, Levy R. The Lewy-body variant of Alzheimer's disease. Clinical and pathological findings. Br J Psychiatry. 1993; 162:385-92. [PubMed: 8453435]

29. Gnanalingham KK, Byrne EJ, Thornton A, Sambrook MA, Bannister P. Motor and cognitive function in Lewy body dementia: comparison with Alzheimer's and Parkinson's diseases. J Neurol Neurosurg Psychiatry. 1997; 62:243-52. [PubMed: 9069479]

30. Mori E, Shimomura T, Fujimori M, Hirono N, Imamura T, Hashimoto M, Tanimukai S, Kazui H, Hanihara T. Visuoperceptual impairment in dementia with Lewy bodies. Arch Neurol. 2000; 57:489-93. [PubMed: 10768622]

31. Mosimann UP, Mather G, Wesnes KA, O’Brien JT, Burn DJ, McKeith IG. Visual perception in Parkinson disease dementia and dementia with Lewy bodies. Neurology. 2004; 63:2091-2096. [PubMed: 15596755]

32. Mosimann UP, Muri RM, Burn DJ, Felblinger J, O’Brien JT, McKeith IG. Saccadic eye movement changes in Parkinson's disease dementia and dementia with Lewy bodies. Brain. 2005; 128:12671276. [PubMed: 15774501]

33. Mito Y, Yoshida K, Yabe I, Makino K, Hirotani M, Tashiro K, Kikuchi S, Sasaki H. Brain 3-DSSP SPECT analysis in dementia with Lewy bodies, Parkinson's disease with and without 
dementia and Alzheimer's disease. Clinical Neurology and Neurosurgery. 2005; 107:396-403. [PubMed: 16023534]

34. Shimuzu S, Hanyu H, Kanetaka H, Iwamoto T, Koizumi K, Abe K. Differentiation of dementia with Lewy bodies from Alzheimer's disease using brain SPECT. Dementia and Geriatric Cognitive Disorders. 2005; 20:25-30. [PubMed: 15832032]

35. Lobotesis K, Fenwick JD, Phipps A, Ryman A, Swann A, Ballard C, McKeith IG, O'Brien JT. Occipital hypoperfusion on SPECT in dementia with Lewy bodies but not AD. Neurology. 2001; 56:643-9. [PubMed: 11245717]

36. Imamura T, Ishii K, Hirono N, Hashimoto M, Tanimukai S, Kazui H, Hanihara T, Sasaki M, Mori E. Occipital glucose metabolism in dementia with lewy bodies with and without Parkinsonism: a study using positron emission tomography. Dement Geriatr Cogn Disord. 2001; 12:194-7. [PubMed: 11244212]

37. Dickson DW, Ruan D, Crystal H, Mark MH, Davies P, Kress Y, Yen SH. Hippocampal degeneration differentiates diffuse Lewy body disease (DLBD) from Alzheimer's disease: light and electron microscopic immunocytochemistry of CA2-3 neurites specific to DLBD. Neurology. 1991; 41:1402-9. [PubMed: 1653914]

38. Dickson DW, Schmidt ML, Lee VM, Zhao ML, Yen SH, Trojanowski JQ. Immunoreactivity profile of hippocampal CA2/3 neurites in diffuse Lewy body disease. Acta Neuropathol (Berl). 1994; 87:269-76. [PubMed: 7912027]

39. Barber R, Gholkar A, Scheltens P, Ballard C, McKeith IG, O’Brien JT. Medial temporal lobe atrophy on MRI in dementia with Lewy bodies. Neurology. 1999; 52:1153-8. [PubMed: 10214736]

40. Johnson DK, Morris JC, Galvin JE. Verbal and visuospatial deficits in dementia with Lewy bodies. Neurology. 2005; 65:1232-8. [PubMed: 16247050]

41. Huber SJ, Paulson GW, Shuttleworth EC. Relationship of motor symptoms, intellectual impairment, and depression in Parkinson's disease. J Neurol Neurosurg Psychiatry. 1988; 51:8558. [PubMed: 3404193]

42. Richards M, Stern Y, Marder K, Cote L, Mayeux R. Relationships between extrapyramidal signs and cognitive function in a community-dwelling cohort of patients with Parkinson's disease and normal elderly individuals. Ann Neurol. 1993; 33:267-74. [PubMed: 8498810]

43. Pearce J. The extrapyramidal disorder of Alzheimer's disease. Eur Neurol. 1974; 12:94-103. [PubMed: 4426320]

44. Molsa PK, Marttila RJ, Rinne UK. Extrapyramidal signs in Alzheimer's disease. Neurology. 1984; 34:1114-6. [PubMed: 6540392]

45. Rinne UK, Laakso K, Molsa PK. Relationship between Parkinson's and Alzheimer's diseases. Involvement of extrapyramidal, dopaminergic, cholinergic, and somatostatin mechanisms in relation to dementia. Acta Neurologica Scandinavica. 1984; 69:59-60.

46. Mayeux R, Stern Y, Spanton S. Heterogeneity in dementia of the Alzheimer type: evidence of subgroups. Neurology. 1985; 35:453-61. [PubMed: 3982631]

47. Crystal HA, Dickson DW, Lizardi JE, Davies P, Wolfson LI. Antemortem diagnosis of diffuse Lewy body disease. Neurology. 1990; 40:1523-8. [PubMed: 2170865]

48. Byrne EJ, Lennox G, Lowe J, Godwin-Austen RB. Diffuse Lewy body disease: clinical features in 15 cases. J Neurol Neurosurg Psychiatry. 1989; 52:709-17. [PubMed: 2545827]

49. Galasko D, Katzman R, Salmon DP, Hansen L. Clinical and neuropathological findings in Lewy body dementias. Brain Cogn. 1996; 31:166-75. [PubMed: 8811993]

50. Gibb WR, Esiri MM, Lees AJ. Clinical and pathological features of diffuse cortical Lewy body disease (Lewy body dementia). Brain. 1987; 110 (Pt 5):1131-53. [PubMed: 2823957]

51. McKeith I, Mintzer J, Aarsland D, Burn D, Chui H, Cohen-Mansfield J, Dickson D, Dubois B, Duda J, Feldman H, Gauthier S, Halliday G, Lawlor B, Lippa C, Lopez O, Mchado JC, O’Brien J, Playfer J, Reid W. on behalf of the International Psychogeriatric Association Expert Meeting on DLB. Dementia with Lewy bodies. Lancet Neurology. 2004; 3:19-28. [PubMed: 14693108]

52. Molloy S, McKeith IG, O'Brien JT, Burn DJ. The role of levodopa in the management of dementia with Lewy bodies. J of Neurol, Neurosurg and Psychiatry. 2005; 76:1200-3. [PubMed: 16107351] 
53. McKeith IG, Fairbairn AF, Perry RH, Thompson P. The clinical diagnosis and misdiagnosis of senile dementia of Lewy body type (SDLT). Br J Psychiatry. 1994; 165:324-32. [PubMed: 7994501]

54. Ferman TJ, Boeve BF, Silber MH, et al. Hallucinations and delusions associated with the REM sleep behavior disorder/dementia syndrome. J Neuropsychiatry Clin Neurosci. 1997; 9:692.

66. Ferman TJ, Boeve BF, Smith GE, Graff-Radford NR. The phenomenology of psychotic features in Dementia with Lewy bodies (DLB) and Alzheimer's disease (AD). Neurology. 2005; 64:A257.

56. Cercy SP, Bylsma FW. Lewy bodies and progressive dementia: a critical review and meta-analysis. J Int Neuropsychol Soc. 1997; 3:179-94. [PubMed: 9126859]

57. Sanchez-Ramos JR, Ortoll R, Paulson GW. Visual hallucinations associated with Parkinson disease. Arch Neurol. 1996; 53:1265-8. [PubMed: 8970453]

58. Harding AJ, Broe GA, Halliday GM. Visual hallucinations in Lewy body disease relate to Lewy bodies in the temporal lobe. Brain. 2002; 125:391-403. [PubMed: 11844739]

59. McKeith I, Fairbairn A, Perry R, Thompson P, Perry E. Neuroleptic sensitivity in patients with senile dementia of Lewy body type. BMJ. 1992; 305:673-8. [PubMed: 1356550]

60. Rockwell E, Choure J, Galasko D, Olichney J, Jeste DV. Psychopathology at initial diagnosis in dementia with Lewy bodies versus Alzheimer disease: comparison of matched groups with autopsy-confirmed diagnoses. Int J Geriatr Psychiatry. 2000; 15:819-23. [PubMed: 10984728]

61. Ala TA, Yang KH, Sung JH, Frey WH 2nd. Hallucinations and signs of parkinsonism help distinguish patients with dementia and cortical Lewy bodies from patients with Alzheimer's disease at presentation: a clinicopathological study. J Neurol Neurosurg Psychiatry. 1997; 62:1621. [PubMed: 9010394]

62. Hope T, Keene J, Fairburn CG, Jacoby R, McShane R. Natural history of behavioural changes and psychiatric symptoms in Alzheimer's disease. A longitudinal study. Br J Psychiatry. 1999; 174:39-44. [PubMed: 10211149]

63. Ferman TJ, Dickson DW, Graff-Radford N, Arvanitakis Z, DeLucia MW, Boeve BF, Parfitt F, Duara R, Barker W, Waters C, Jimison PG, Brassler SJ. Early onset of visual hallucinations in dementia distinguishes pathologically-confirmed Lewy body disease from AD. Neurology. 2003; 60(5):A264.

64. Salmon DP, Kwo-on-Yuen PF, Heindel WC, Butters N, Thal LJ. Differentiation of Alzheimer's disease and Huntington's disease with the Dementia Rating Scale. Arch Neurol. 1989; 46:1204-8. [PubMed: 2530966]

65. Ballard C, Bannister C, Graham C, Oyebode F, Wilcock G. Associations of psychotic symptoms in dementia sufferers. Br J Psychiatry. 1995; 167:537-40. [PubMed: 8829726]

66. Klein C, Kompf D, Pulkowski U, Moser A, Vieregge P. A study of visual hallucinations in patients with Parkinson's disease. J Neurol. 1997; 244:371-7. [PubMed: 9249622]

67. Lopez OL, Becker JT, Brenner RP, Rosen J, Bajulaiye OI, Reynolds CF 3rd. Alzheimer's disease with delusions and hallucinations: neuropsychological and electroencephalographic correlates. Neurology. 1991; 41:906-12. [PubMed: 2046938]

68. Lopez OL, Brenner RP, Becker JT, Ulrich RF, Boller F, DeKosky ST. EEG spectral abnormalities and psychosis as predictors of cognitive and functional decline in probable Alzheimer's disease. Neurology. 1997; 48:1521-5. [PubMed: 9191759]

69. Boeve B, Silber M, Ferman T. REM sleep behavior disorder in Parkinson's disease and dementia with Lewy bodies. J Geriatr Psychiatry Neurol. 2004; 17:146-157. [PubMed: 15312278]

70. Boeve BF, Silber MH, Parisi JE, Dickson DW, Ferman TJ, Benarroch EE, Schmeichel AM, Smith GE, Petersen RC, Ahlskog JE, Matsumoto JY, Knopman DS, Schenck CH, Mahowald MW. Synucleinopathy pathology and REM sleep behavior disorder plus dementia or parkinsonism. Neurology. 2003; 61:40-45. [PubMed: 12847154]

71. Lopez OL, Hamilton RL, Becker JT, Wisniewski S, Kaufer DI, DeKosky ST. Severity of cognitive impairment and the clinical diagnosis of AD with Lewy bodies. Neurology. 2000; 54:1780-7. [PubMed: 10802784]

72. Hohl U, Tiraboschi P, Hansen LA, Thal LJ, Corey-Bloom J. Diagnostic accuracy of dementia with Lewy bodies. Arch Neurol. 2000; 57:347-51. [PubMed: 10714660] 
73. Walker MP, Ayre GA, Perry EK, Wesnes K, McKeith IG, Tovee M, Edwardson JA, Ballard CG. Quantification and characterization of fluctuating cognition in dementia with Lewy bodies and Alzheimer's disease. Dement Geriatr Cogn Disord. 2000; 11:327-35. [PubMed: 11044778]

74. Ballard CG, Aarsland D, McKeith I, O'Brien J, Gray A, Cormack F, Burn D, Cassidy T, Starfeldt R, Larsen JP, Brown R, Tovee M. Fluctuations in attention: PD dementia vs DLB with parkinsonism. Neurology. 2002; 59:1714-20. [PubMed: 12473758]

75. Ballard C, Walker M, O'Brien J, Rowan E, McKeith I. The characterisation and impact of 'fluctuating' cognition in dementia with Lewy bodies and Alzheimer's disease. Int J Geriatr Psychiatry. 2001; 16:494-8. [PubMed: 11376465]

76. Ballard C, O’Brien J, Gray A, Cormack F, Ayre G, Rowan E, Thompson P, Bucks R, McKeith I, Walker M, Tovee M. Attention and fluctuating attention in patients with dementia with Lewy bodies and Alzheimer disease. Arch Neurol. 2001; 58:977-82. [PubMed: 11405813]

77. Ferman TJ, Smith GE, Boeve BF, et al. DLB fluctuations: specific features that reliably differentiate DLB from AD and normal aging. Neurology. 2004; 62:181-187. [PubMed: 14745051]

78. Ferman TJ, Boeve BF, Silber MH, Lin SC, Fredrickson PA. Is fluctuating cognition in dementia with sleep. Sleep. 2001; 24:374. [PubMed: 11403521]

79. Boeve BF, Ferman TJ, Silber MH, Lin SC, Fredrickson PA, Smith GE, Lucas JA, Knopman D, Graff-Radford NR, Geda YE, Ivnik RJ, Petersen RC. Sleep disturbances in dementia with Lewy bodies involve more than REM sleep behavior disorder. Neurology. 2003; 60(5):A79.

80. Kales A, Ansel RD, Markham CH, Scharf MB, Tan TL. Sleep in patients with Parkinson's disease and normal subjects prior to and following levodopa administration. Clin Pharmacol Ther. 1971; 12:397-406. [PubMed: 4325251]

81. Wetter TC, Collado-Seidel V, Pollmacher T, Yassouridis A, Trenkwalder C. Sleep and periodic leg movement patterns in drug-free patients with Parkinson's disease and multiple system atrophy. Sleep. 2000; 23:361-7. [PubMed: 10811380]

82. Bliwise DL. Sleep in normal aging and dementia. Sleep. 1993; 16:40-81. [PubMed: 8456235]

83. American Sleep Disorders Association. The international classification of sleep disorders diagnostic and coding manual. Rochester, Minnesota: American Sleep Disorders Association; 1997.

84. Jouvet M, Delorme F. [Locus coeruleus et sommeil paradoxal]. C R Seances Soc Biol Fil. 1965; 159:895-899.

85. Lai YY, Siegel JM. Physiological and anatomical link between Parkinson-like disease and REM sleep behavior disorder. Mol Neurobiol. 2003; 27:137-52. [PubMed: 12777684]

86. Hendricks JC, Morrison AR, Mann GL. Different behaviors during paradoxical sleep without atonia depend on pontine lesion site. Brain Res. 1982; 239:81-105. [PubMed: 7093693]

87. Lu J, Sherman D, Devor M, Saper C. A putative flip-flop switch for control of REM sleep. Nature. 2006; 441:589-594. [PubMed: 16688184]

88. Plazzi G, Corsini R, Provini F, Pierangeli G, Martinelli P, Montagna P, Lugaresi E, Cortelli P. REM sleep behavior disorders in multiple system atrophy. Neurology. 1997; 48:1094-7. [PubMed: 9109907]

89. Gagnon JF, Bedard MA, Fantini ML, Petit D, Panisset M, Rompre S, Carrier J, Montplaisir J. REM sleep behavior disorder and REM sleep without atonia in Parkinson's disease. Neurology. 2002; 59:585-9. [PubMed: 12196654]

90. Schenck CH, Bundlie SR, Mahowald MW. Delayed emergence of a parkinsonian disorder in 38\% of 29 older men initially diagnosed with idiopathic rapid eye movement sleep behaviour disorder. Neurology. 1996; 46:388-93. [PubMed: 8614500]

91. Turner RS, Chervin RD, Frey KA, Minoshima S, Kuhl DE. Probable diffuse Lewy body disease presenting as REM sleep behavior disorder. Neurology. 1997; 49:523-7. [PubMed: 9270589]

92. Boeve BF, Silber MH, Ferman TJ, Lucas JA, Parisi JE. Association of REM sleep behavior disorder and neurodegenerative disease may reflect an underlying synucleinopathy. Mov Disord. 2001; 16:622-30. [PubMed: 11481685] 
93. Uchiyama M, Isse K, Tanaka K, Yokota N, Hamamoto M, Aida S, Ito Y, Yoshimura M, Okawa M. Incidental Lewy body disease in a patient with REM sleep behavior disorder. Neurology. 1995; 45:709-12. [PubMed: 7723959]

94. Boeve BF, Dickson DW, Olson EJ, et al. Insights into REM sleep behavior disorder pathophysiology in brainstem-predominant Lewy body disease. Sleep Medicine. 2007; 8:60-64. [PubMed: 17157062]

95. Boeve BF, Silber MH, Saper CB, et al. Pathophysiology of REM sleep behavior disorder and relevance to neurodegenerative disease. Brain. in press.

96. Thaisetthawatkul P, Boeve BF, Benarroch EE, Sandroni P, Ferman TJ, Petersen R, Low PA. Autonomic dysfunction in dementia with Lewy bodies. Neurology. 2004; 62:1804-1809. [PubMed: 15159482]

97. Stern Y, Albert M, Brandt J, Jacobs DM, Tang MX, Marder K, Bell K, Sano M, Devanand DP, Bylsma F, et al. Utility of extrapyramidal signs and psychosis as predictors of cognitive and functional decline, nursing home admission, and death in Alzheimer's disease: prospective analyses from the Predictors Study. Neurology. 1994; 44:2300-7. [PubMed: 7991116]

98. Armstrong TP, Hansen LA, Salmon DP, Masliah E, Pay M, Kunin JM, Katzman R. Rapidly progressive dementia in a patient with the Lewy body variant of Alzheimer's disease. Neurology. 1991; 41:1178-80. [PubMed: 1714056]

99. Olichney JM, Galasko D, Salmon DP, Hofstetter CR, Hansen LA, Katzman R, Thal LJ. Cognitive decline is faster in Lewy body variant than in Alzheimer's disease. Neurology. 1998; 51:351-7. [PubMed: 9710002]

100. Ballard C, Patel A, Oyebode F, Wilcock G. Cognitive decline in patients with Alzheimer's disease, vascular dementia and senile dementia of Lewy body type. Age Ageing. 1996; 25:209_ 13. [PubMed: 8670554]

101. Ballard C, O'Brien J, Morris CM, Barber R, Swann A, Neill D, McKeith I. The progression of cognitive impairment in dementia with Lewy bodies, vascular dementia and Alzheimer's disease. Int J Geriatr Psychiatry. 2001; 16:499-503. [PubMed: 11376466]

102. Helmes E, Bowler JV, Merskey H, Munoz DG, Hachinski VC. Rates of cognitive decline in Alzheimer's disease and dementia with Lewy bodies. Dement Geriatr Cogn Disord. 2003; 15:6771. [PubMed: 12566594]

103. Williams MM, Xiong C, Morris JC, Galvin JE. Survival and mortality differences between dementia with Lewy bodies vs. Alzheimer's disease. Neurology. 2006; 67:1935-1941. [PubMed: 17159097]

104. Dickson DW. Dementia with Lewy bodies: neuropathology. J Geriatr Psychiatry Neurol. 2002; 15:210-6. [PubMed: 12489917]

105. Pollanen MS, Dickson DW, Bergeron C. Pathology and biology of the Lewy body. J Neuropathol Exp Neurol. 1993; 52:183-91. [PubMed: 7684074]

106. Dickson DW, Davies P, Mayeux R, Crystal H, Horoupian DS, Thompson A, Goldman JE. Diffuse Lewy body disease. Neuropathological and biochemical studies of six patients. Acta Neuropathol (Berl). 1987; 75:8-15. [PubMed: 3434218]

107. Dickson DW, Feany MB, Yen SH, Mattiace LA, Davies P. Cytoskeletal pathology in nonAlzheimer degenerative dementia: new lesions in diffuse Lewy body disease, Pick's disease, and corticobasal degeneration. J Neural Transm Suppl. 1996; 47:31-46. [PubMed: 8841955]

108. Kosaka K, Yoshimura M, Ikeda K, Budka H. Diffuse type of Lewy body disease: progressive dementia with abundant cortical Lewy bodies and senile changes of varying degree--a new disease? Clin Neuropathol. 1984; 3:185-92. [PubMed: 6094067]

109. Braak H, Braak E. Pathoanatomy of Parkinson's disease. J Neurol. 2000; 247 Suppl 2:II3-10. [PubMed: 10991663]

110. Braak H, Del Tredici K, Rub U, de Vos RA, Jansen Steur EN, Braak E. Staging of brain pathology related to sporadic Parkinson's disease. Neurobiol Aging. 2003; 24:197-211. [PubMed: 12498954]

111. Kosaka K. Diffuse Lewy body disease in Japan. J Neurol. 1990; 237:197-204. [PubMed: 2196340] 
112. Whitwell JL, Jack CR, Parisi JE, et al. Rates of cerebral atrophy differ in different degenerative pathologies. Brain. In press.

113. Whitwell JL, Weigand SD, Josephs KA, et al. Focal atrophy in dementia with Lewy bodies on MRI. a distinct pattern from Alzheimer's disease. Brain. In press.

114. Dickson DW. Neuropathological diagnosis of Alzheimer's disease: a perspective from longitudinal clinicopathological studies. Neurobiol Aging. 1997; 18:S21-6. [PubMed: 9330981]

115. Lippa CF, Smith TW, Perry E. Dementia with Lewy bodies: choline acetyltransferase parallels nucleus basalis pathology. J Neural Transm. 1999; 106:525-35. [PubMed: 10443555]

116. Dickson DW, Crystal H, Mattiace LA, Kress Y, Schwagerl A, Ksiezak-Reding H, Davies P, Yen SH. Diffuse Lewy body disease: light and electron microscopic immunocytochemistry of senile plaques. Acta Neuropathol (Berl). 1989; 78:572-84. [PubMed: 2683563]

117. Dickson DW. The pathogenesis of senile plaques. J Neuropathol Exp Neurol. 1997; 56:321-39. [PubMed: 9100663]

118. Armstrong RA, Cairns NJ, Lantos PL. Beta-amyloid deposition in the temporal lobe of patients with dementia with Lewy bodies: comparison with non-demented cases and Alzheimer's disease. Dement Geriatr Cogn Disord. 2000; 11:187-92. [PubMed: 10867443]

119. Jellinger KA. Morphological substrates of mental dysfunction in Lewy body disease: an update. J Neural Transm Suppl. 2000; 59:185-212. [PubMed: 10961431]

120. Katzman R, Brown T, Thal LJ, Fuld PA, Aronson M, Butters N, Klauber MR, Wiederholt W, Pay $\mathrm{M}$, Xiong RB, et al. Comparison of rate of annual change of mental status score in four independent studies of patients with Alzheimer's disease. Ann Neurol. 1988; 24:384-9. [PubMed: 3228273]

121. Dickson DW, Crystal HA, Mattiace LA, Masur DM, Blau AD, Davies P, Yen SH, Aronson MK. Identification of normal and pathological aging in prospectively studied nondemented elderly humans. Neurobiol Aging. 1992; 13:179-89. [PubMed: 1311804]

122. Hansen LA, Masliah E, Galasko D, Terry RD. Plaque-only Alzheimer disease is usually the lewy body variant, and vice versa. J Neuropathol Exp Neurol. 1993; 52:648-54. [PubMed: 8229084]

123. Samuel W, Galasko D, Masliah E, Hansen LA. Neocortical lewy body counts correlate with dementia in the Lewy body variant of Alzheimer's disease. J Neuropathol Exp Neurol. 1996; 55:44-52. [PubMed: 8558171]

124. Braak H, Braak E. Neuropathological stageing of Alzheimer-related changes. Acta Neuropathol (Berl). 1991; 82:239-59. [PubMed: 1759558]

125. Samuel W, Alford M, Hofstetter CR, Hansen L. Dementia with Lewy bodies versus pure Alzheimer disease: differences in cognition, neuropathology, cholinergic dysfunction, and synapse density. J Neuropathol Exp Neurol. 1997; 56:499-508. [PubMed: 9143263]

126. Merdes AR, Hansen LA, Jeste DV, Galasko D, Hofstetter CR, Ho GJ, Thal LJ, Corey-Bloom J. Influence of Alzheimer pathology on clinical diagnostic accuracy in dementia with Lewy bodies. Neurology. 2003; 60:1586-1590. [PubMed: 12771246]

127. Del Ser T, Hachinski V, Merskey H, Munoz D. Clinical and pathologic features of two groups of patients with Dementia with Lewy bodies: Effect of coexisting Alzheimer-type lesion load. Alzheimer Dis and Assoc Dis. 2001; 15:31-44.

128. Samuel WA, Henderson VW, Miller CA. Severity of dementia in Alzheimer disease and neurofibrillary tangles in multiple brain regions. Alzheimer Dis Assoc Disord. 1991; 5:1-11. [PubMed: 2025419]

129. Arriagada PV, Growdon JH, Hedley-Whyte ET, Hyman BT. Neurofibrillary tangles but not senile plaques parallel duration and severity of Alzheimer's disease. Neurology. 1992; 42:631-9. [PubMed: 1549228]

130. Haroutunian V, Serby M, Purohit DP, Perl DP, Marin D, Lantz M, Mohs RC, Davis KL. Contribution of Lewy body inclusions to dementia in patients with and without Alzheimer disease neuropathological conditions. Arch Neurol. 2000; 57:1145-50. [PubMed: 10927794]

131. Hurtig HI, Trojanowski JQ, Galvin J, Ewbank D, Schmidt ML, Lee VM, Clark CM, Glosser G, Stern MB, Gollomp SM, Arnold SE. Alpha-synuclein cortical Lewy bodies correlate with dementia in Parkinson's disease. Neurology. 2000; 54:1916-21. [PubMed: 10822429] 
132. Churchyard A, Lees AJ. The relationship between dementia and direct involvement of the hippocampus and amygdala in Parkinson's disease. Neurology. 1997; 49:1570-6. [PubMed: 9409348]

133. Ransmayr G, Cervera P, Hirsch EC, Berger W, Fischer W, Agid Y. Alzheimer's disease: is the decrease of the cholinergic innervation of the hippocampus related to intrinsic hippocampal pathology? Neuroscience. 1992; 47:843-51. [PubMed: 1374541]

134. West MJ, Coleman PD, Flood DG, Troncoso JC. Differences in the pattern of hippocampal neuronal loss in normal aging and Alzheimer's disease. Lancet. 1994; 344:769-72. [PubMed: 7916070]

135. Nagy Z, Jobst KA, Esiri MM, Morris JH, King EM, MacDonald B, Litchfield S, Barnetson L, Smith AD. Hippocampal pathology reflects memory deficit and brain imaging measurements in Alzheimer's disease: clinicopathologic correlations using three sets of pathologic diagnostic criteria. Dementia. 1996; 7:76-81. [PubMed: 8866679]

136. Harding AJ, Lakay B, Halliday GM. Selective hippocampal neuron loss in dementia with Lewy bodies. Ann Neurol. 2002; 51:125-8. [PubMed: 11782993]

137. Lippa CF, Pulaski-Salo D, Dickson DW, Smith TW. Alzheimer's disease, Lewy body disease and aging: a comparative study of the perforant pathway. J Neurol Sci. 1997; 147:161-6. [PubMed: 9106122]

138. Mesulam MM, Mufson EJ, Levey AI, Wainer BH. Cholinergic innervation of cortex by the basal forebrain: cytochemistry and cortical connections of the septal area, diagonal band nuclei, nucleus basalis (substantia innominata), and hypothalamus in the rhesus monkey. J Comp Neurol. 1983; 214:170-97. [PubMed: 6841683]

139. Himmelheber AM, Sarter M, Bruno JP. The effects of manipulations of attentional demand on cortical acetylcholine release. Brain Res Cogn Brain Res. 2001; 12:353-70. [PubMed: 11689296]

140. McGaughy J, Kaiser T, Sarter M. Behavioral vigilance following infusions of 192 IgG-saporin into the basal forebrain: selectivity of the behavioral impairment and relation to cortical AChEpositive fiber density. Behav Neurosci. 1996; 110:247-65. [PubMed: 8731052]

141. McGaughy J, Everitt BJ, Robbins TW, Sarter M. The role of cortical cholinergic afferent projections in cognition: impact of new selective immunotoxins. Behav Brain Res. 2000; 115:251-63. [PubMed: 11000424]

142. Torres EM, Perry TA, Blockland A, Wilkinson LS, Wiley RG, Lappi DA, Dunnet SB. Behavioural, histochemical and biochemical consequences of selective immunolesions in discrete regions of the basal forebrain cholinergic system. Neuroscience. 1994; 63:95-122. [PubMed: 7898665]

143. Voytko ML, Olton DS, Richardson RT, Gorman LK, Tobin JR, Price DL. Basal forebrain lesions in monkeys disrupt attention but not learning and memory. J Neurosci. 1994; 14:167-86. [PubMed: 8283232]

144. Davis KL, Mohs RC, Marin D, et al. Cholinergic markers in elderly patients with early signs of Alzheimer disease. JAMA. 1999; 281(15):1401-1406. [PubMed: 10217056]

145. Perry EK, Irving D, Kerwin JM, McKeith IG, Thompson P, Collerton D, Fairbairn AF, Ince PG, Morris CM, Cheng AV, et al. Cholinergic transmitter and neurotrophic activities in Lewy body dementia: similarity to Parkinson's and distinction from Alzheimer disease. Alzheimer Dis Assoc Disord. 1993; 7:69-79. [PubMed: 8347330]

146. Perry EK, Haroutunian V, Davis KL, Levy R, Lantos P, Eagger S, Honavar M, Dean A, Griffiths M, McKeith IG, et al. Neocortical cholinergic activities differentiate Lewy body dementia from classical Alzheimer's disease. Neuroreport. 1994; 5:747-9. [PubMed: 8018843]

147. Tiraboschi P, Hansen LA, Alford M, Merdes A, Masliah E, Thal LJ, Corey-Bloom J. Early and widespread cholinergic losses differentiate dementia with Lewy bodies from Alzheimer disease. Arch Gen Psychiatry. 2002; 59:946-51. [PubMed: 12365882]

148. Perry EK, Perry RH. Acetylcholine and hallucinations: disease-related compared to drug-induced alterations in human consciousness. Brain Cogn. 1995; 28:240-58. [PubMed: 8546852]

149. Perry R, McKeith I, Perry E. Lewy body dementia--clinical, pathological and neurochemical interconnections. J Neural Transm Suppl. 1997; 51:95-109. [PubMed: 9470131] 
150. Tune LE, Egeli S. Acetylcholine and delirium. Dement Geriatr Cogn Disord. 1999; 10:342-4. [PubMed: 10473936]

151. Flacker JM, Cummings V, Mach JR Jr, Bettin K, Kiely DK, Wei J. The association of serum anticholinergic activity with delirium in elderly medical patients. Am J Geriatr Psychiatry. 1998; 6:31-41. [PubMed: 9469212]

152. Han L, McCusker J, Cole M, Abrahamowicz M, Primeau F, Elie M. Use of medications with anticholinergic effect predicts clinical severity of delirium symptoms in older medical inpatients. Arch Intern Med. 2001; 161:1099-105. [PubMed: 11322844]

153. Tune LE, Damlouji NF, Holland A, Gardner TJ, Folstein MF, Coyle JT. Association of postoperative delirium with raised serum levels of anticholinergic drugs. Lancet. 1981; 2:651-3. [PubMed: 6116042]

154. Perry E, Walker M, Grace J, Perry R. Acetylcholine in mind: a neurotransmitter correlate of consciousness? Trends Neurosci. 1999; 22:273-80. [PubMed: 10354606]

155. Lebert F, Pasquier F, Souliez L, Petit H. Tacrine efficacy in Lewy body dementia. Int J Geriatr Psychiatry. 1998; 13:516-9. [PubMed: 9733331]

156. Wengel SP, Roccaforte WH, Burke WJ. Donepezil improves symptoms of delirium in dementia: implications for future research. J Geriatr Psychiatry Neurol. 1998; 11:159-61. [PubMed: 9894735]

157. Samuel W, Caligiuri M, Galasko D, Lacro J, Marini M, McClure FS, Warren K, Jeste DV. Better cognitive and psychopathologic response to donepezil in patients prospectively diagnosed as dementia with Lewy bodies: a preliminary study. Int J Geriatr Psychiatry. 2000; 15:794-802. [PubMed: 10984725]

158. Maclean LE, Collins CC, Byrne EJ. Dementia with Lewy bodies treated with rivastigmine: effects on cognition, neuropsychiatric symptoms, and sleep. Int Psychogeriatr. 2001; 13:277-88. [PubMed: 11768375]

159. Bergman J, Lerner V. Successful use of donepezil for the treatment of psychotic symptoms in patients with Parkinson's disease. Clin Neuropharmacol. 2002; 25:107-10. [PubMed: 11981238]

160. Francis J, Martin D, Kapoor WN. A prospective study of delirium in hospitalized elderly. Jama. 1990; 263:1097-101. [PubMed: 2299782]

161. Moore DP. Rapid treatment of delirium in critically ill patients. Am J Psychiatry. 1977; 134:1431-2. [PubMed: 920848]

162. Allen RL, Walker Z, D'Ath PJ, Katona CL. Risperidone for psychotic and behavioural symptoms in Lewy body dementia. Lancet. 1995; 346:185. [PubMed: 7541499]

163. Miller CH, Mohr F, Umbricht D, Woerner M, Fleischhacker WW, Lieberman JA. The prevalence of acute extrapyramidal signs and symptoms in patients treated with clozapine, risperidone, and conventional antipsychotics. J Clin Psychiatry. 1998; 59:69-75. [PubMed: 9501888]

164. Burke WJ, Pfeiffer RF, McComb RD. Neuroleptic sensitivity to clozapine in dementia with Lewy bodies. J Neuropsychiatry Clin Neurosci. 1998; 10:227-9. [PubMed: 9608415]

165. Sechi G, Agnetti V, Masuri R, Deiana GA, Pugliatti M, Paulus KS, Rosati G. Risperidone, neuroleptic malignant syndrome and probable dementia with Lewy bodies. Prog Neuropsychopharmacol Biol Psychiatry. 2000; 24:1043-51. [PubMed: 11041543]

166. Rosebush PI, Mazurek MF. Neurologic side effects in neuroleptic-naive patients treated with haloperidol or risperidone. Neurology. 1999; 52:782-5. [PubMed: 10078728]

167. Piggott MA, Perry EK, Marshall EF, McKeith IG, Johnson M, Melrose HL, Court JA, Lloyd S, Fairbairn A, Brown A, Thompson P, Perry RH. Nigrostriatal dopaminergic activities in dementia with Lewy bodies in relation to neuroleptic sensitivity: comparisons with Parkinson's disease. Biol Psychiatry. 1998; 44:765-74. [PubMed: 9798081]

168. Court JA, Piggott MA, Lloyd S, Cookson N, Ballard CG, McKeith IG, Perry RH, Perry EK. Nicotine binding in human striatum: elevation in schizophrenia and reductions in dementia with Lewy bodies, Parkinson's disease and Alzheimer's disease and in relation to neuroleptic medication. Neuroscience. 2000; 98:79-87. [PubMed: 10858614]

169. Cummings JL, Street J, Masterman D, Clark WS. Efficacy of olanzapine in the treatment of psychosis in dementia with Lewy bodies. Dementia and Geriatric Cognitive Disorders. 2002; 13:67-73. [PubMed: 11844887] 
170. Aarsland D, Larsen JP, Lim NG, Tandberg E. Olanzapine for psychosis in patinets with Parkinson's disease with and without dementia. J of Neuropsy and Clin Neurosc. 1999; 11:392394.

171. Ellingrod VL, Schultz SK, Ekstam-Smith K, Kutscher E, Turvey C, Arndt S. Comparison of risperdone with olanzepine in elderly patients with dementia and psychosis. Pharmacotherapy. 2002; 22:1-5. [PubMed: 11794418]

172. Mulsant BH, Gharabawi GM, Bossie CA, Mao L, Martinez RA, Tune LE, Greenspan AJ, Bastean JN, Pollock BG. Correlates of anticholinergic activity in patients with dementia and psychosis treated with risperidone or olanzepine. J of Clinical Psychiatry. 2004; 65:1708-1714. [PubMed: 15641877]

173. Ballard C, Margallo-Lana M, Juszczak E, Swann DS, O’Brien TA, Everratt A, Sadler S, Maddison C, Lee L, Bannister C, Elvish R, Jacoby R. Quetiapine and rivastigmine and cognitive decline in Alzheimer's disease: randomised double blind placebo controlled trial. BMJ. 2005; 333:857-858.

174. Juncos JL, Roberts VJ, Evatt ML, Jewart RD, Wood CD, Potter LS, Jou HC, Yeung PP. Quetiapine improves psychotic symptoms and cognition in Parkinson's disease. Movement Disorders. 2004; 19:29-35. [PubMed: 14743357]

175. Morrison CE, Borod JC, Brin MF, Halbig TD, Olanow CW. Effects of levodopa on cognitive functioning in moderate-to-severe Parkinson's disease (MSPD). J of Neural Transmission. 2004; 111:1333-1341.

176. Kulisevsky J, Garcia-Sanchez C, Berthier ML, Barbanoj M, Pascual-Sedano B, Gironell A, Estevez-Gonzalez A. Chronic effects of dopaminergic replacement on cognitive function in Parkinson's disease: a two-year follow-up study of previously untreated patients. Movement Disorders. 2000; 15:613-626. [PubMed: 10928571]

177. Bedard MA, Pillon B, Dubois B, Duchesne N, Masson H, Agid Y. Acute and long-term administration of anticholinergics in Parkinson's disease: specific effects on the subcorticofrontal syndrome. Brain Cogn. 1999; 40:289-313. [PubMed: 10413563]

178. McKeith I, Del Ser T, Spano P, Emre M, Wesnes K, Anand R, Cicin-Sain A, Ferrara R, Spiegel R. Efficacy of rivastigmine in dementia with Lewy bodies: a randomised, double-blind, placebocontrolled international study. Lancet. 2000; 356:2031-6. [PubMed: 11145488]

179. Kaufer DI, Catt KE, Lopez OL, DeKosky ST. Dementia with Lewy bodies: response of deliriumlike features to donepezil. Neurology. 1998; 51:1512. [PubMed: 9818904]

180. Wilcock GK, Scott MI. Tacrine for senile dementia of Alzheimer's or Lewy body type. Lancet. 1994; 344:544. [PubMed: 7914636]

181. Levy R, Eagger S, Griffiths M, Perry E, Honavar M, Dean A, Lantos P. Lewy bodies and response to tacrine in Alzheimer's disease. Lancet. 1994; 343:176. [PubMed: 7904023]

182. Grace J, Daniel S, Stevens T, Shankar K, Walker Z, Byrne EJ, Butler S, Wilkinson D, Woolford J, Waite J, McKeith IG. Long term use of rivastigmine in patients with dementia with Lewy bodies: an open-label trials. International Psychogeriatrics. 2001; 13:199-205. [PubMed: 11495394]

183. Bosboom JL, Stoffers D, Wolters ECh. Cognitive dysfunction and dementia in Parkinson's disease. J of Neural Transm. 2004; 111:1303-1315. [PubMed: 15480840]

184. Samuel W, Caligiuri M, Galasko D, Lacro J, Marini M, McClure FS, Warren K, Jeste DV. Better cognitive and psychopathologic response to donepezil in patients prospectively diagnosed as dementia with Lewy bodies: a preliminary study. International J of Geriatric Psychiatry. 2000; 15:794-802.

185. Minett TS, Thomas A, Wilkinson LM, Daniel SL, Sanders J, Richardson J, Littlewood E, Myint P, Newby J, McKeith IG. What happens when donepezil is suddently withdrawn? An open label trial in dementia with Lewy bodies and Parkinson's disease with dementia. International J of Geriatric Psychiatry. 2003; 18:988-993.

186. Thomas AJ, Burn DJ, Rowan EN, Littlewood E, Newby J, Cousins D, Pakrasi S, Richardson J, Sanders J, McKeith IG. A comparison of the efficacy of donepezil in Parkison's disease with dementia and dementia with Lewy bodies. Int J Geriatr Psychiatry. 2005; 20:938-44. [PubMed: 16163744] 
187. Cummings J. Reconsidering diagnostic criteria for dementia with Lewy bodies. Highlights from the Third International Workshop on Dementia with Lewy bodies and Parkinson's disease dementia, September 17-20, 2003, Newcastle upon Tyne, United Kingdom. Rev Neurol Dis. 2004; 1(1):31-34. [PubMed: 16397449]

188. Boeve B, Silber M, Ferman TJ, et al. Current management of sleep disturbances in dementia. Curr Neurol Neurosci Rep. 2001; 2:169-177. [PubMed: 11898484]

189. Boeve B, Silber M, Ferman T. Melatonin for treatment of REM sleep behavior disorder in neurologic disorders: results in 14 patients. Sleep med. 2003; 4:281-284. [PubMed: 14592300]

190. Boeve B, Silber M, Ferman T. Rem sleep behavior disorder in Parkinson's disease and dementia with lewy bodies. J Geriatr Psychiatry Neurol. 2004; 17:146-157. [PubMed: 15312278]

191. Carlson D, Fleming K, Smith GE, Evans J. Management of dementia-related behavioral disturbances: a non-pharmacological approach. Mayo Clinic Proceedings. 1995; 70:1108-1115. [PubMed: 7475342]

192. Haupt M, Karger A, Janner M. Improvement of agitation and anxiety in demented patients after psychoeducative group intervention with their caregivers. International $\mathrm{J}$ of Geriatric Psychiatry. 2000; 15:1125-1129.

193. Zarit SH, Stephens MA, Townsend A, Greene R. Stress reduction for family caregivers: effect of adult day care use. J of Gerontology. 1998; 53:S267-S277. 
Table 1

Revised criteria for the clinical diagnosis of Dementia with Lewy bodies (DLB)

1 Central feature (essential for a diagnosis of possible or probable DLB)

- Dementia defined as progressive cognitive decline of sufficient magnitude to interfere with normal social or occupational function

- Prominent or persistent memory impairment may not necessarily occur in the early stages but is usually evident with progression.

- Deficits on tests of attention, executive function and visuospatial ability may be especially prominent.

2 Core features (2 core features are sufficient for a diagnosis of probable DLB, 1 for possible DLB.

- $\quad$ Fluctuating cognition with pronounced variation in attention and alertness.

- $\quad$ Recurrent visual hallucinations that are typically well formed and detailed.

- $\quad$ Spontaneous features of parkinsonism

3 Suggestive features (if 1 or more of these is present in the presence of one or more core features, a diagnosis of probable DLB can be made. In the absence of any core features, one or more suggestive features is sufficient for possible DLB. Probable DLB should not be diagnosed on the basis of suggested features alone.)

- $\quad$ REM sleep behavior disorder

- Severe neuroleptic sensitivity

- Low dopamine transporter uptake in the basal ganglia demonstrated by SPECT or PET imaging

From McKeith IG, Dickson DW, Lowe J, et al., Diagnosis and management of dementia with Lewy bodies: Third report of the DLB consortium. Neurology, 65:1863-1872, 2005. 